\title{
PENINGKATAN DAYA SAING USAHA JASA PENYEDIA MAKANAN DAN MINUMAN DENGAN PENDEKATAN MANAJEMEN DI MOTHERLAND COFFEE
}

\begin{abstract}
Amlys Syahputra Silalahi ${ }^{1}$, Rina Bukit ${ }^{2}$, Doli Muhammad Ja'Far Dalimunthe ${ }^{3}$, Aryanti Sariartha Sianipar ${ }^{4}$, Ance Marintan Sitohang ${ }^{5}$
\end{abstract}
1) Fakultas Ekonomi dan Bisnis, Universitas Sumatera Utara
E-mail: amlys@usu.ac.id
2) Fakultas Ekonomi dan Bisnis, Universitas Sumatera Utara
E-mail: rina.bukit@usu.ac.id
3) Fakultas Ekonomi dan Bisnis, Universitas Sumatera Utara
E-mail: dolidalimunthe@usu.ac.id
4) Fakultas Ekonomi dan Bisnis, Universitas Sumatera Utara
E-mail: aryantisariartha@usu.ac.id
5) Fakultas Ekonomi dan Bisnis, Universitas Sumatera Utara
E-mail: ance_mds@usu.ac.id

\begin{abstract}
Motherland Coffee merupakan salah satu merek kopi gerobak pada awal pendiriannya, namun pemilik usaha kafe ini menemukan rekan usaha yang memberikannya lokasi untuk dikelola sesuai merk kafe yang pernah berkembang. Pengelola terdiri dari lima orang dengan konsep kerja paruh waktu dan pembagian tugas secara merata. Secara manajemen usaha kafe belum memiliki pembagian kerja berdasarkan konsep Manajemen yang memadai. Pembagian kerja bukan pada basis spesialisasi dan berbasis kebersamaan. Pada aspek SDM personil yang mengelola belum memiliki standar spesifikasi jabatan dan deskripsi pekerjaan. Pada aspek keuangan, penjualan dicatat secara harian dengan menggunakan aplikasi "QASIR" yang menampilkan statistik produk terjual dan nilai transaksi. Namun, pencatatan laporan keuangan seperti neraca, laba rugi, dan arus kas belum diterapkan. Untuk meningkatkan ekspansi operasional, maka diperlukan konsep usaha yang matang agar dapat mencari sumber pendanaan baik dari investor maupun perbankan. Solusi yang ditawarkan untuk permasalahan organisasi antara lain dengan pendekatan Manajemen Fayol yakni merumuskan struktur organisasi, deskripsi pekerjaan, spesifikasi jabatan. Pada aspek pemasaran adalah dengan merumuskan teknik promosi pemasaran digital. Secara manajamen keuangan solusi yang ditawarkan adalah dengan pencatatan transaksi untuk laporan keuangan, dan business plan sebagai alat untuk mendapatkan sumber modal bagi ekspansi operasional usaha.
\end{abstract}

Keyword:

\section{PENDAHULUAN}

\subsection{Analisis Situasi}

Bisnis kafe merupakan salah satu bisnis yang banyak dikembangkan di daerah kotakota besar di Indonesia. Berdasarkan data yang disajikan oleh media Marketeers terdapat potensi yang besar dari usaha penyediaan makanan dan minuman di Indonesia.
Tabel 1. Nilai Penjualan dan Pertumbuhan Layanan Makanan berdasarkan Subesektor, 2014 Dalam Jutaan Dolar AS

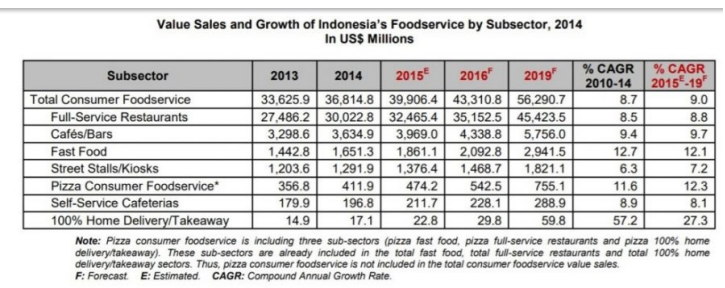


Amlys et.al. Peningkatan Daya Saing Usaha Jasa Penyedia Makanan Dan Minuman Dengan Pendekatan Manajemen Di Motherland Coffee

Sumber: Marketeers.com (2019)

Berdasarkan data tersebut dapat dilihat bahwa potensi nilai penjualan kafe dari tahun 2013 hingga 2014 mengalami peningkatan. Prediksi pada tahun 2019 nilai penjualan kafe sebesar 5,7 Milyar Dolar AS. Sementara itu pertumbuhan tahunan penjualan kafe diprediksi sebesar 9,7\%/tahun mulai tahun mulai 2015 hingga 2019. Berdasarkan fakta tersebut maka merupakan satu hal yang wajar jika masyarakat di kota-kota besar tertarik untuk membuka usaha layanan penyedia makanan dan minuman (kafe), termasuk di kota Medan.

Jumlah kafe di Medan bisa mencapai ratusan gerai baik yang sifatnya franchise maupun UMKM. Namun, usaha kafe yang dikelola secara individu oleh pebisnis Usaha Mikro, Kecil, dan Menengah. Ketika pebisnis mulai memasuki usaha kafe, terdapat sejumlah dana yang sudah diinvestasikan dalam bentuk aset-aset berwujud seperti bangunan, peralatan, modal kerja. Nilai investasi yang paling kecil mulai Rp 25 juta hingga ratusan juta rupiah. Tujuan dari investasi tersebut adalah agar sumber daya yang telah diinvestasikan dapat memberikan keuntungan. Agar dapat bersaing dengan kafe-kafe lain dengan manajemen yang lebih baik maka diperlukan suatu sistem manajemen yang lebih terstruktur mulai dari Operasional hingga Keuangan. Sistem manajemen yang terarah juga diperlukan agar kafe dapat berkembang dan layak mendapatkan sumber modal yang lebih besar dari investor maupun perbankan.

Salah satu kafe yang dimiliki oleh pebisnis individu di Medan yang menjadi mitra dalam pengabdian masyarakat ini adalah kafe Motherland Coffee yang terletak di daerah sekitar kampus Universitas Sumatera Utara.

\subsubsection{Profil Mitra}

Kafe Motherland Coffee merupakan kafe yang digagas oleh salah seorang pendirinya Matchius Sinulingga yang terletak di Jalan
Berdikari No. 103 Padang Bulan, Medan Sumatera Utara. Usaha ini dirintis bersama partner usahanya Erwin. Kafe tersebut dikelola Matchius bersama empat orang rekan kerjanya, yaitu Konstantinus Karokaro; Priska Berutu; dan Rizki Wahyuni, dan Muchtar Sibarani. Motherland Coffee terletak pada satu lokasi yang cukup strategis karena berada di sekitar pemukiman mahasiswa. Luas bangunan tempat kafe beroperasi juga cukup luas. Memulai usaha dari gerobak kopi, Matchius memutuskan untuk meningkatkan kapasitas usahanya dengan bergabung bersama Erwin. Erwin sebagai pihak yang memiliki lokasi lalu mempercayakan pengelolaan lokasi untuk dirancang menjadi sebuah kafe dengan nama kopi yang dikelola Matchius sebelumnya. Sistem gerobak kopi tersebut kemudian dilepasnya ke pihak lain dan kini fokus mengelola kafe dengan ruang yang lebih luas.

Adapun gambar lokasi kafe tersebut ditampilkan pada gambar 1. Sementara itu, peta lokasi Motherland Coffe dapat dicari pada Google Maps dengan kata kunci nama kafe tersebut. Peta lokasi dapat dilihat pada gambar 2. Lokasi kafe dekat dengan kampus Fakultas Pertanian Univesitas Sumatera Utara dan berada di sekitar kos mahasiswa serta pemukiman penduduk. Jalan pada lokasi cukup dilewati kendaraan roda empat. Kafe ini memiliki kapasitas pengunjung yang cukup besar, dapat memuat 50 pengunjung dalam waktu bersamaan. Jam operasional kafe dibagi dalam dua jadwal Senin hingga Sabtu mulai pukul 12.00 s.d. 24.00 WIB dan Minggu mulai pukul 19.00 s.d. 24.00 WIB. Operasional kafe secara efektif mulai 17 Mei 2019 pada lokasi yang baru tersebut. Menu yang dijual beragam mulai menu makanan seperti Nasi Ayam Penyet, Nasi Goreng, Mie Goreng, dan Mie Instan hingga minuman seperti Teh Manis Dingin dan aneka kopi. Selain menu makanan, fasilitas yang disediakan adalah WiFi, dan parkir kendaraan yang cukup luas. 
Amlys et.al. Peningkatan Daya Saing Usaha Jasa Penyedia Makanan Dan Minuman Dengan Pendekatan Manajemen Di Motherland Coffee

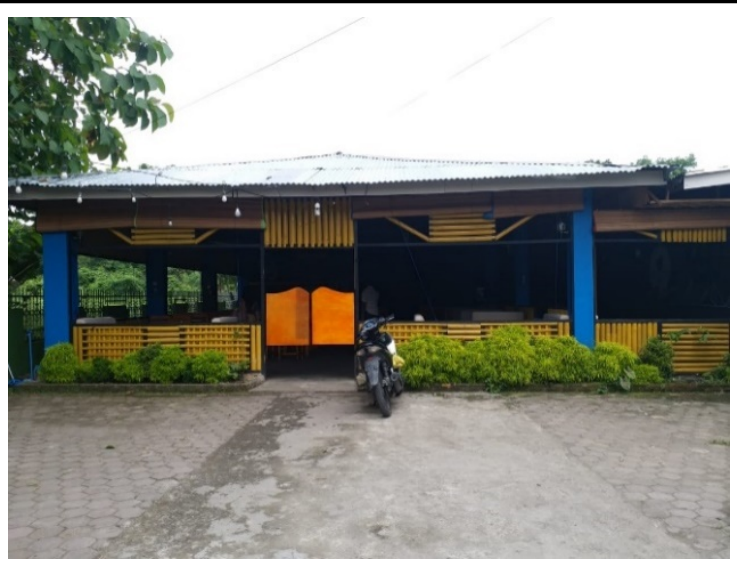

Sumber: Dokumentasi Pribadi

Gambar 1. Kafe Motherland Coffee Tampak Depan

\subsubsection{Segi Produksi dan Manajemen Usaha}

Produksi kafe menggunakan teknik produksi manual dengan formulasi roasting kopi oleh tim produksi. Setelah roasting, bubuk kopi juga diracik dengan takaran yang sudah ditentukan. Proses roasting menggunakan mesin tersendiri. Permasalahan produksi tergolong dalam kategori yang khusus dan tidak terdapat permasalahan.

Manajemen usaha masih belum sesuai dengan teori Manajemen pada umumnya. Berdasarkan prinsip Manajemen Fayol terdapat 14 prinsip yang dapat diterapkan dalam segala bentuk organisasi (Robins \& Coulter, 2016):

1. Pembagian kerja. Spesialisasi bidang kerja akan meningkatkan output karena mampu memampukan para karyawan bekerja lebih efisien.

2. Kewenangan. Para manajer harus mampu memberikan perintah dan kewenangan merupakan dasar yang memampukan

mereka melakukannya.

3. Disiplin. Para karyawan harus mematuhi dan menghormati aturanaturan yang berlaku dalam organisasi.
4. Kesatuan perintah. Setiap pekerja harus menerima perintah dari hanya satu orang atasan saja.

5. Kesatuan arahan. Organisasi harus memiliki sebuah rencana kerja yang berlaku seragam dan yang dapat dijadikan panduan bagi manajer dan pekerja.

6. Penundukan kepentingan pribadi di bawah kepentingan umum.

7. Remunerasi (imbalan jasa). Para pekerja harus memperoleh upah yang adil untuk jasa (kerja) yang telah mereka berikan.

8. Pemusatan (sentralisasi). Seberapa jauh bawahan dapat terlibat dalam pengambilan keputusan.

9. Rantai komando.

10. Keteraturan. Orang-orang dan barang-barang harus berada di tempat yang tepat pada waktu yang tepat pula.

11. Keselayakan (ekuitas). Para manajer harus bersikap secara pantas dan adil pada karyawan.

12. Kestabilan posisi dan jabatan karyawan. Manajemen harus merancang penempatan kerja karyawan yang tertib dan teratur, serta memastikan tersedianya pengganti jika terjadi kekosongan posisi/jabatan.

13. Inisiatif. Para karyawan yang diizinkan untuk membuat dan melaksanakan rencana-rencana kerja harus mencurahkan segala daya upaya untuk memastikan keberhasilan rencana kerja.

14. Semangat kekeluargaan. Semangat kebersamaan akan membangun keselarasan dan persatuan organisasi. 
Amlys et.al. Peningkatan Daya Saing Usaha Jasa Penyedia Makanan Dan Minuman Dengan Pendekatan Manajemen Di Motherland Coffee

\section{Berdasarkan hasil observasi}

ditemukan beberapa hal terkait manajemen usaha yang diterapkan:

1. Secara manajemen masih belum terencana secara detil. Berdasarkan hasil observasi di lapangan terdapat empat orang pengelola kafe tersebut. Keempat orang tersebut bekerja secara paruh waktu dengan jam kerja fleksibel.

2. Belum ada pembagian kerja yang spesifik di antara para pengelola. Secara struktur juga tidak diketahui siapa yang memegang rantai komando dan arahan dalam organisasi.

3. Pembagian kerja berdasarkan pada bobot pekerjaan yang dinyatakan dibagi secara merata. Aktivitas pekerjaan tersebut antara lain untuk belanja bahan baku, pengembangan konsep bisnis, pemasaran, dan penjaminan kualitas bahan baku.

4. Terdapat kendala disiplin dan manajemen waktu pada pengelola disebabkan bentuk waktu kerja paruh waktu.

5. Aspek Operasional/ Produksi tidak terdapat pembagian di antara pengelola: siapa yang menjadi juru masak, juru racik kopi, bagian pelayanan, dan kasir. Meskipun secara kualitas produk kopi yang dihasilkan dapat bersaing dengan kualitas produk kafe-kafe lainnya.

6. Aspek Pemasaran terbatas pada cakupan lingkaran kerabat para pengelola. Selain mengandalkan lingkaran pertemanan, promosi melalui media sosial juga dilakukan.

7. Aspek Sumber Daya Manusia sudah memadai dari sisi jumlah personil. Personil terdiri dari empat orang pengelola. Semua pengelola dapat mengerjakan semua pekerjaan selama waktu yang dimiliki cukup untuk melakukan

tersebut.

8. Aspek Keuangan. Harga Pokok Produk sudah ditentukan melalui bantuan aplikasi "QASIR" yang dapat diakses pada Google Playstore. Selain itu, secara harian semua pengelola bersama melakukan rekapitulasi dan penghitungan jumlah penjualan dan pengeluaran. Melalui bantuan aplikasi tersebut pengelola dapat mencatat penjualan yang diperoleh setiap harinya. Tidak hanya itu, statistik nilai penjualan dan jumlah produk yang terjual dapat diketahui. Namun tidak untuk catatan pengeluaran. Di sisi lain tidak terdapat buku neraca, laporan laba rugi, dan laporan arus kas dalam usaha. Margin produk ditentukan $<100 \%$.

9. Pengelola menentukan pembagian keuntungan dengan skema sebagai berikut:

a) $40 \%$ keuntungan bagi pengusaha sebelumnya yang memiliki aset usaha

b) $50 \%$ keuntungan bagi pengelola keuntungan ini yang dibagikan secara merata kepada para pengelola. Hal ini ditempuh untuk memberikan remunerasi yang pantas bagi pengelola kafe. Pengelola akan memiliki sense of belonging terhadap kafe tersebut dengan skenario pembagian keuntungan tersebut.

c) $10 \%$ keuntungan bagi operasional

10. Pengelola memiliki rencana untuk mengembangkan usaha hingga ke tingkatan integrasi vertikal, mulai dari hulu hingga hilir bisnis.

11. Berdasarkan dasar teori Manajemen tersebut, terdapat beberapa prinsip yang telah dipenuhi oleh Manajemen Motherland Coffee, yaitu penundukan kepentingan pribadi di 
Amlys et.al. Peningkatan Daya Saing Usaha Jasa Penyedia Makanan Dan Minuman Dengan Pendekatan Manajemen Di Motherland Coffee

bawah kepentingan umum;
remunerasi; keselayakan; kestabilan
posisi dan jabatan karyawan; inisiatif;
dan semangat kekeluargaan

\subsection{Permasalahan Mitra}

\subsubsection{Permasalahan Produksi dan Manajemen yang Disepakati}

Secara produksi tidak terdapat permasalahan yang dihadapi oleh pihak kafe, Sebab sebelumnya mereka telah memiliki pasar untuk produk kopi yang dipasarkan. Pada 1 minggu pertama operasional terdapat 327 produk yang terjual dengan 150 transaksi apabila dikonversi ke dalam nilai penjualan dengan rata-rata harga $\mathrm{Rp} 10.000$ maka nominal penjualan adalah Rp 3.270.000. Menu yang disediakan dapat dilihat pada gambar 3 . Tampilan menu masih dalam bentuk sederhana.

Berdasarkan hasil kesepakatan
dengan mitra terdapat beberapa
permasalahan yang diidentifikasi, yaitu:

1. Aspek Manajemen, yaitu beberapa prinsip Manajemen perlu disusun secara lebih detil.

2. Aspek Sumber Daya Manusia, yaitu adanya kesulitan pembagian waktu dan prioritas antara para pengelola sebab bekerja secara paruh waktu.

3. Aspek Pemasaran, perlu adanya model promosi yang lebih beragam agar Motherland Coffee semakin dikenal oleh kalangan mahasiswa yang merupakan segmen utama kafe ini. Pengelola telah merencanakan beberapa event untuk mempromosikan kafe tersebut.

4. Aspek Keuangan, melakukan pencatatan keuangan yang lebih detil khususnya posisi neraca dan laporan arus kas serta laba rugi usaha.
5. Aspek Operasional, pengelola berharap dapat melakukan integrasi usaha hulu dan hilir dengan menguasai proses rantai nilai produksi. Namun, rencana tersebut terkendala masalah pendanaan untuk perluasan operasi.

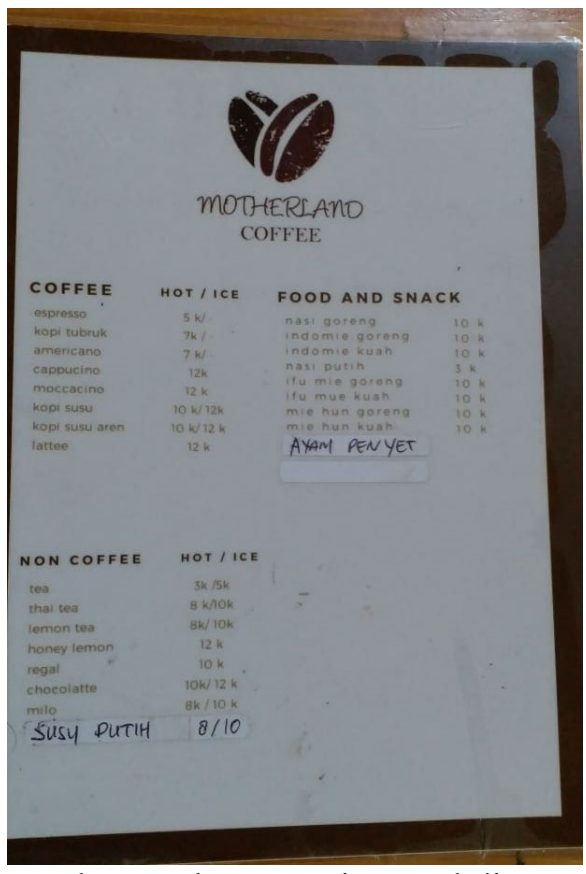

Sumber: Dokumentasi Pengabdi

\section{Gambar 3. Menu Motherland Coffee}

\subsubsection{Persoalan Prioritas yang Disepakati untuk Diselesaikan}

Berdasarkan identifikasi permasalahan tersebut maka mitra dan pengabdi bersepakat untuk menyelesaikan persoalan yang berada pada aspek manajemen, sumber daya manusia, aspek keuangan, dan operasional. Aspek Manajemen akan diselesaikan dengan menyusun struktur organisasi pengelola, pembagian kerja, disiplin, kesatuan wewenang, dan kesetuan arahan, rantai komando, dan keteraturan. Berikutnya adalah aspek sumber daya manusia dengan melakukan perumusan job description untuk setiap struktur organisasi yang ditentukan. Selain itu membuat skedul kerja bagi para pengelola berdasarkan kesepakatan bersama. Pada aspek pemasaran, pengabdi dapat membantu melakukan promosi dan memberikan 
alternatif model promosi yang lebih beragam dan tepat bagi segmentasi yang telah ditetapkan. Pembuatan laporan keuangan seperti posisi neraca, laporan arus kas, serta laba rugi usaha akan menjadi masalah yang juga diselesaikan untuk dapat mengetahui kondisi sesungguhnya dari usaha tersebut dan sebagai alat perencanaan manajemen berikutnya. Tujuan akhir untuk membantu permodalan bagi rencana integrasi vertikal bisnis, akan dilakukan pembekalan penyusunan Business Plan yang efektif untuk mendapatkan pendanaan dari investor/perbankan.

\section{METODE PELAKSANAAN}

\subsection{Permasalahan Aspek Manajemen}

a. Aspek manajemen yang mengalami kendala adalah pada prinsip pembagian kerja, disiplin, kesatuan wewenang, dan kesetuan arahan, rantai komando, dan keteraturan. Solusi yang ditawarkan dapat terlaksana dengan melakukan konsultasi bisnis secara tatap muka. Pengabdi dapat memberikan pengarahan materi sebagai pemahaman awal bagi para pengelola kafe. Kemudian setelah terdapat pemahaman, akan dilakukan praktek langsung dengan merumuskan struktur organisasi dan pembagian kerja, serta rantai komando pada organisasi pengelola.

b. Permasalahan pada aspek MSDM adalah tidak adanya dokumen Job Specification yang berisi tugas dan tanggung jawab para pengelola berdasarkan posisi dan jabatan yang menjadi bagiannya. Tahapan pelaksanaan dimulai dengan memberikan pengarahan materi kepada pengelola secara tatap muka. Selanjutnya dengan menyelesaikan kasus di lapangan dengan hasil akhir adalah dokumen job specification dan job description organisasi. c. Model promosi yang ada pada usaha kafe mitra adalah pada lingkaran kerabat para pengelola dan media sosial. Selain itu, segmentasi pasar juga sudah sangat jelas. Namun, terdapat model promosi lain yang bisa dijadikan solusi agar dapat meningkatkan penjualan. Tahapan dalam pelaksanaan adalah dengan memberikan pengarahan materi tentang teknik promosi kafe yang tepat bagi para pengelola. Setelah itu dilakukan praktek merumuskan model promosi kafe Motherland Coffee.

d. Model pencatatan transaksi menjadi keterbatasan bagi para pengelola. Agar dapat menghasilkan laporan keuangan maka tahapannya dimulai dengan mengidentifikasi transaksi yang berkaitan dengan penambahan modal, pembelian peralatan, dan nilai persediaan yang ada serta transaksi pemasukan dan pengeluaran. Apabila telah dilakukan identifikasi transaksi tersebut, selanjutnya disusun laporan keuangan dengan bantuan aplikasi akuntansi UMKM.

e. Persoalan operasional yang berkaitan dengan ekspansi akan dapat diselesaikan apabila pengelola kafe memahami cara membuat Business Plan yang menarik bagi investor. Tahapannya dimulai dengan memberikan arahan materi business plan dan dilanjutkan dengan eksekusi pembuatan perencanaan bisnis Motherland Coffee oleh para pengelola.

\subsection{Peran Mitra}

Mitra dalam pengabdian masyarakat memiliki partisipasi sebagai berikut:

1. Menyediakan informasi yang dibutuhkan dalam penyelesaian persoalan yang disepakati bersama.

2. Menjadi pihak yang mempelajari arahan materi pada aspek yang 
Amlys et.al. Peningkatan Daya Saing Usaha Jasa Penyedia Makanan Dan Minuman Dengan Pendekatan Manajemen Di Motherland Coffee

bermasalah dan solusi yang ditawarkan.

3. Bekerja sama dengan pengabdi untuk menerapkan materi yang telah disampaikan sesuai dengan aspekaspek tersebut sehingga luaran dapat tercapai.

\section{HASIL YANG DICAPAI}

a. Aspek Manajemen yang diusulkan adalah 14 prinsip Manajemen Fayol dan spesialisasi kerja Adam Smith.

b. Dokumen spesifikasi jabatan (job specification) dan deskripsi pekerjaan (job description) dirumuskan untuk jabatan penting di kedai kopi. Salah satunya adalah barista. Dokumen tersebut ditampilkan dalam gambar 4 dan gambar 5 .

\section{Jabatan: Barista}

\section{Uraian jabatan secara umum:} membuat dan menyajikan kopi kepada pelanggan; membuat kopi espresso, serta meracik kopi dengan berbagai campuran, seperti kopi latte atau cappucino.

Tugas yang penting (40\%): Operasional mesin pembuat kopi (mesin espresso) Tugas-tugasnya: mengukur besar suhu dan tekanan untuk membuat espresso

Tugas yang penting (40\%): Peracikan berbagai varian kopi (cappucino, latte, dll)

Tugas-tugas: membuat berbagai varian kopi yang menggunakan susu dan menambahkannya ke dalam espresso sesuai dengan takaran terbaik,

Tugas yang penting (10\%): Membuat minuman selain kopi

Tugas-tugas: meracik minuman yang terdapat pada menu warung kopi seperti teh, jus, dan coklat.

Tugas yang penting (10\%):

Membersihkan Coffee Bar (Mesin Espresso)

Tugas-tugas: memeriksa dan mejaga kebersihan mesin espresso secara berkala

Fungsi-fungsi yang tidak penting Tugas-tugas lain yang diberikan seperti membersihkan area kedai kopi, memberikan pelayanan tambahan kepada pelanggan

Sumber: Rumusan Pengabdi dan Mitra Gambar 4. Deskripsi Pekerjaan Barista 
Amlys et.al. Peningkatan Daya Saing Usaha Jasa Penyedia Makanan Dan Minuman Dengan Pendekatan Manajemen Di Motherland Coffee

\section{Jabatan: Barista}

\section{Uraian jabatan secara umum:} membuat dan menyajikan kopi kepada pelanggan; membuat kopi espresso, serta meracik kopi dengan berbagai campuran, seperti kopi latte atau cappucino.

Kualifikasi:

a. Mengenal jenis-jenis kopi dan racikan kopi dengan berbagai varian (espreso, cappucino, latte)

b. Memahami proses pembuatan kopi dan teknik-teknik peracikan kopi/ latte art

\section{c. Mampu mengoperasikan mesin espreso}

d. Mampu membuat kopi dengan teknik froth, steam, foam susu sebagai campuran kopi

e. Mampu membuat jenis minuman selain kopi seperti teh, jus, coklat

f. Memiliki kepribadian yang ramah, dan berorientasi pada pelanggan

g. Memiliki motivasi kerja dan prestasi tinggi

h. Bersedia diberikan tugas membersihkan area kedai kopi

Sumber: Rumusan Pengabdi dan Mitra

Gambar 5. Deskripsi Pekerjaan Barista

c. Model pencatatan transaksi keuangan dimulai dengan mengumpulkan bukti transaksi dan mengurutkannya berdasarkan tanggal transaksi. Menggunakan aplikasi Akuntansi UKM- Keuangan dengan menggunakan aplikasi android yang bisa diperoleh pada google playstore.

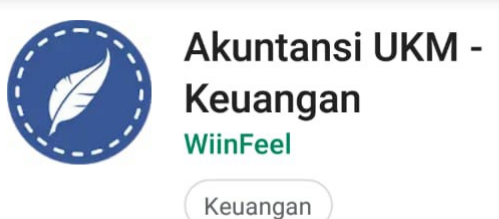

UNINSTAL BUKA

Pembelian dalam ap

Apa yang baru $\bullet$

Terakhir diupdate 3 Nov 2018

Sehubungan dengan kebijakan google

mengharuskan meningkatkan kode versi

aplikasi membuat beberapa perintah error. Sedi

\section{SELENGKAPNYA}

Beri nilai aplikasi ini

Sampaikan pendapat Anda

Sumber: Google Playstore

Gambar 6. Aplikasi Laporan Keuangan UMKM pada Android

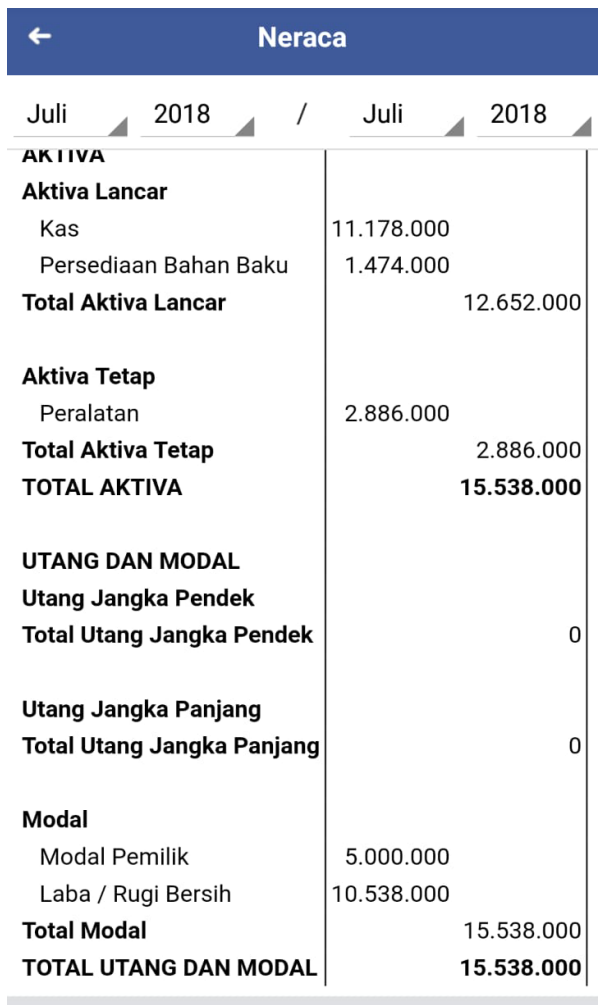

Sumber: Aplikasi Akuntansi

Gambar 7. Laporan Neraca Luaran yang Dicapai 
Amlys et.al. Peningkatan Daya Saing Usaha Jasa Penyedia Makanan Dan Minuman Dengan Pendekatan Manajemen Di Motherland Coffee

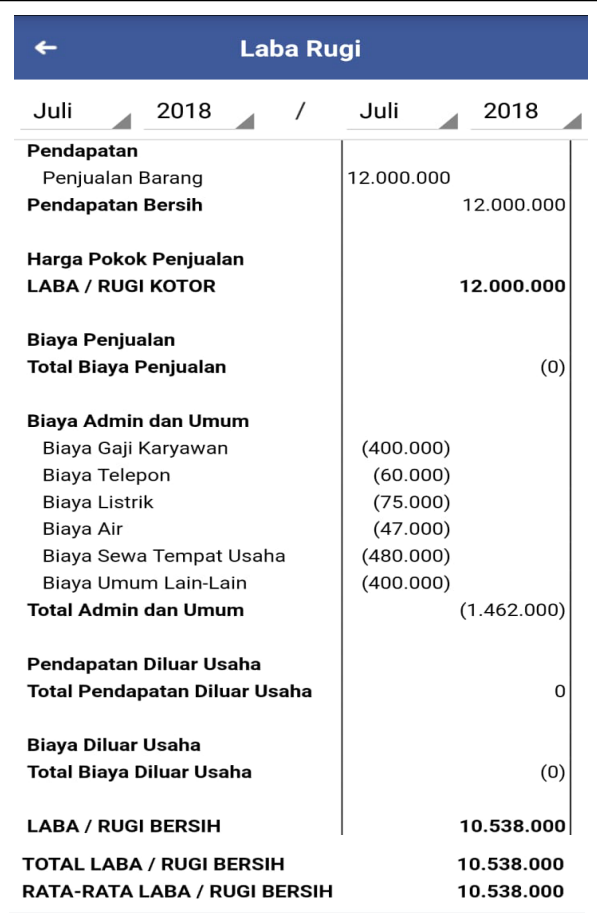

Gambar 8. Laporan Laba Rugi

d. Business plan yang dirumuskan untuk memperoleh pendanaan lanjutan bagi pengembangan usaha.

\section{KESIMPULAN DAN SARAN}

Berdasarkan kegiatan pengabdian ini Mitra lebih menyadari pentingnya pendekatan Manajemen pada usaha kedai kopi yang dimiliki. Sebagai salah satu usaha dengan fokus pada ritel dan Franchise diperlukan adanya spesialisasi kerja yang lebih jelas sehingga dapat meningkatkan produktivitas usaha.

Sebelum aktivitas pengabdian, masing-masing pekerja melakukan semua pekerjaan tanpa ada pembagian kerja yang spesifik. Ketika diperhadapkan pada ekspansi usaha dan pengembangan lebih lanjut maka perlu mendefinisikan sistem yang lebih baik. Masing-masing pengelola memiliki jabatan dengan deskripsi dan spesifikasi jabatan. Terdapat satu rantai komando yang memberikan instruksi dalam mengelola kafe. Melalui penyuluhan dan pendampingan yang dilakukan pemilik dan pengelola meningkat kesadarannya akan pentingnya Manajemen dalam kedai kopi. Sebagai pelengkap, diberikan penyuluhan mengenai penyusunan rencana bisnis (business plan) untuk pengajuan modal pinjaman/dana investasi dari perbankan dan investor. Melalui pendekatan Manajemen Fayol; rumusan kebutuhan sumber daya manusia yang tertera dalam deskripsi dan spesifikasi jabatan; rumusan media promosi melalui pemasaran digital dan media sosial, serta laporan keuangan yang ada dapat meyakinkan pihak pemberi dana untuk meminjamkan dan menginvestasikan uang pada usaha ini.

Saran bagi pengabdian berikutnya agar mampu melakukan evaluasi dari penerapan Manajemen dalam kedai kopi. Evaluasi terlebih dilakukan pada Manajamen Keuangan untuk laporan laba rugi dan neraca agar diperoleh gambaran mengenai kinerja pengelolaan kedai kopi.

\section{UCAPAN TERIMA KASIH}

Tim Pengabdi mengucapkan terima kasih kepada Lembaga Pengabdian Pada Masyarakat (LPPM) Universitas yang telah memberikan dana dengan skema Dosen Wajib Mengabdi. Ucapan terima kasih juga disampaikan kepada mitra pengabdi, Motherland Coffee dan pekerja-pekerja yang membantu terlaksananya kegiatan.

\section{DAFTAR PUSTAKA}

Robins, S. P., \& Coulter, M. (2016). Management (Vol. 13). London: Pearson Education Inc. 